\title{
OPEN Retraction Note: Doubled haploid production in alfalfa (Medicago sativa $L$.) through isolated microspore culture
}

\author{
Dengxia Yij ${ }^{1}$, Jifeng Sun ${ }^{2}$, Yanbin $\mathrm{Su}^{3}$, Zongyong Tong ${ }^{1}$, Tiejun Zhang $^{1}$ \& Zan Wang ${ }^{1}$
}

Retraction of: Scientific Reports https://doi.org/10.1038/s41598-019-45946-x, published online 01 July 2019

This article has been retracted by the authors because it was submitted without the knowledge or consent of the last author.

All authors agreed to the retraction.

(c) Open Access This article is licensed under a Creative Commons Attribution 4.0 International (c) License, which permits use, sharing, adaptation, distribution and reproduction in any medium or format, as long as you give appropriate credit to the original author(s) and the source, provide a link to the Creative Commons license, and indicate if changes were made. The images or other third party material in this article are included in the article's Creative Commons license, unless indicated otherwise in a credit line to the material. If material is not included in the article's Creative Commons license and your intended use is not permitted by statutory regulation or exceeds the permitted use, you will need to obtain permission directly from the copyright holder. To view a copy of this license, visit http://creativecommons.org/licenses/by/4.0/.

(C) The Author(s) 2019

${ }^{1}$ Institute of Animal Science, Chinese Academy of Agricultural Sciences, Beijing, 100193, China. ${ }^{2}$ Weifang Academy of Agricultural Science, Weifang, Shandong, 261071, China. ${ }^{3}$ Beijing Zhongnong Futong Horticulture Corporation Limited, Beijing, 100193, China. Correspondence and requests for materials should be addressed to D.Y. (email: yidengxia@163.com)or Z.W. (email:wangzancaas@163.com) 